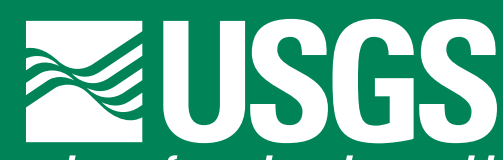

science for a changing world

Prepared in cooperation with

Idaho Department of Environmental Quality

\title{
Assessment of Fish Assemblages and Minimum Sampling Effort Required to Determine Biotic Integrity of Large Rivers in Southern Idaho, 2002
}

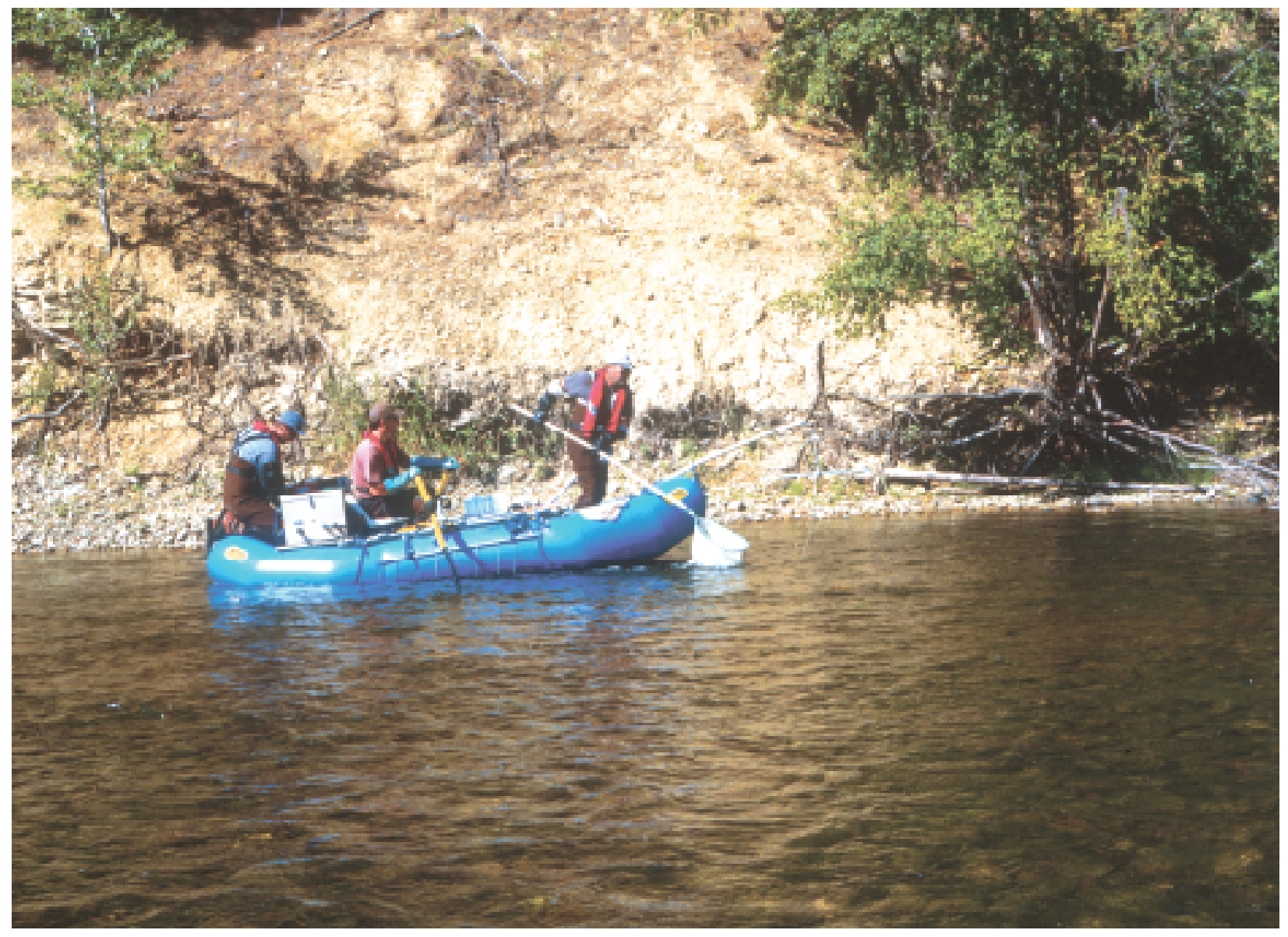

Water-Resources Investigations Report 03-4274

Version 1.1

U.S. Department of the Interior

U.S. Geological Survey 
Note changes effective November 30, 2005, Version I.I release date.

Page 6. Analytical Methods: The methods describe modifying the ten metric index of biological integrity (IBI) described by Mebane and others (2003) for use with the reduced data collected in the present study. Only nine metrics could be calculated with the lengths of fish, making estimates of the numbers of salmonid age classes observed unreliable. However, because of an error in the spreadsheet provided to the authors by Christopher A. Mebane, the IBI scores were in fact calculated as if data for all ten metrics were available. This caused all IBI scores to have a $10 \%$ low bias. Because this bias was systematic and slight, it did not affect any of the patterns observed or the conclusions reached. The values are internally comparable as presented in the report, but they should not be compared to IBI values external to this report without dividing the scores by $0.9(9 / 10)$ to account for reduced EMAP data set.

Page 9. Table 3. In the table row labeled "Final IBI score," all values should be divided by $0.9(9 / 10)$ to be comparable with IBI scores described in Mebane and others (2003).

Page 13. Table 4. In table column labeled "IBI score," all values should be divided by $0.9(9 / 10)$ to be consistent with the IBI described in Mebane and others (2003).

Cover: U.S. Geological Survey employees electrofishing in the Salmon River near Challis, Idaho (photo by William H. Clark, Idaho Department of Environmental Quality) 


\section{Assessment of Fish Assemblages and Minimum Sampling Effort Required to Determine Biotic Integrity of Large Rivers in Southern Idaho, 2002}

By Terry R. M aret and Douglas S. Ott 


\title{
U.S. Department of the Interior Gale A. Norton, Secretary
}

\author{
U.S. Geological Survey \\ Charles G. Groat, Director
}

U.S. Geological Survey, Reston, Virginia; 2004

For more information about the USGS and its products:

Telephone: 1-888-ASK-USGS

World Wide Web: http://www.usgs.gov/

\begin{abstract}
Any use of trade, product, or firm names in this publication is for descriptive purposes only and does not imply endorsement by the U.S. Government.

Although this report is in the public domain permission must be secured from the individual copyright owners to
\end{abstract} reproduce any copyrighted materials contained within this report.

Maret, T.R., and Ott, D.S., 2004, Assessment of Fish Assemblages and Minimum Sampling Effort Required to Determine Biotic Integrity of Large Rivers in Southern Idaho, 2002: U.S. Geological Survey Water-Resources Investigations Report $03-4274,16$ p. 


\section{Contents}

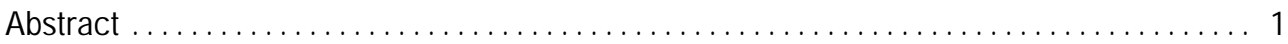

Introduction $\ldots \ldots \ldots \ldots \ldots \ldots \ldots \ldots \ldots \ldots \ldots \ldots \ldots \ldots \ldots \ldots \ldots \ldots \ldots \ldots$

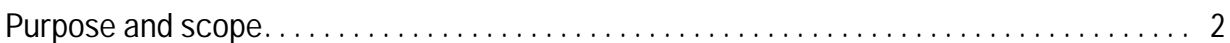

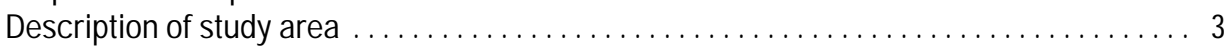

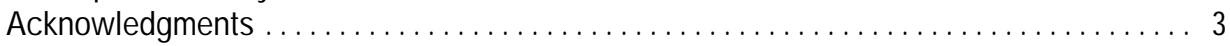

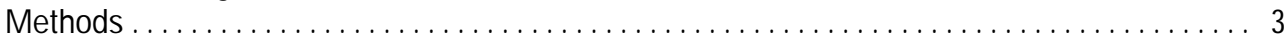

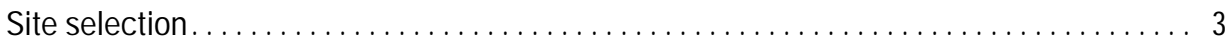

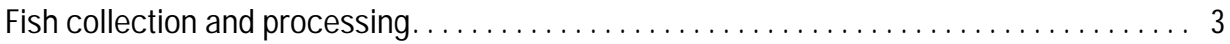

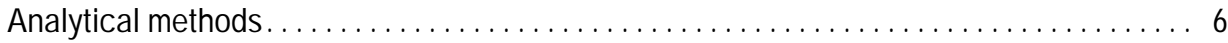

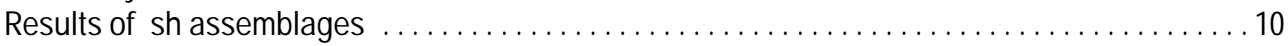

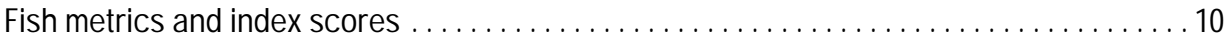

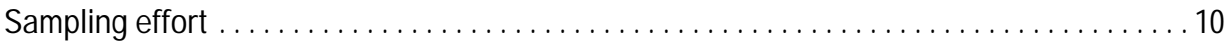

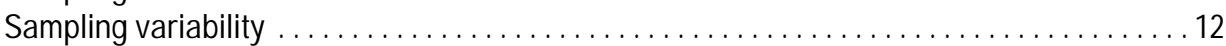

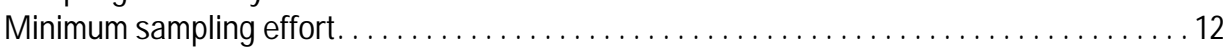

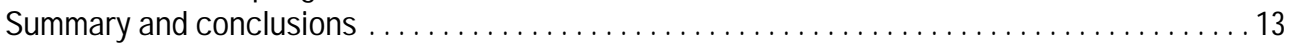

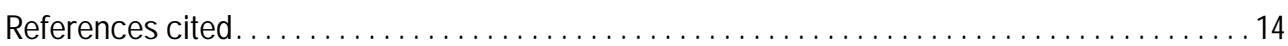

\section{Figures}

1. M ap showing location of study area, Environmental M onitoring and Assessment Program (EM AP) sampling sites, and bioregions in southern Idaho, $2002 \ldots \ldots \ldots .4$

2. Number of subreaches in relation to percent cumulative sh species collected over a sampling distance of 40 channel widths in 14 river reaches in southern

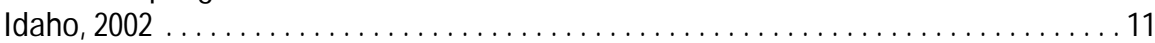

3. N umber of subreaches in relation to number of sh species collected over a sampling distance of 100 channel widths in the Snake River at Heise and near Marsing, and in the Payette River near Emmett, southern Idaho, $2002 \ldots \ldots \ldots \ldots \ldots 1$

4. Number of sh in relation to percent cumulative species collected over a sampling distance of 40 channel widths in 14 river reaches in southern Idaho,

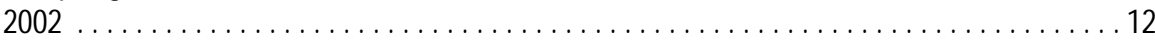

5. Mean number of sh collected over a sampling distance equal to 40 channel widths in 10 equidistant subreaches in 14 river reaches in southern Idaho, 2002 . . . . 12

6. Cumulative Index of Biotic Integrity scores over a sampling distance equal to 100 channel widths in 10 equidistant subreaches in the Snake River at Heise and near M arsing, and in the Payette River near Emmett, southern Idaho, 2002 


\section{Tables}

1. Basin and site characteristic for all sites sampled for the Environmental M onitoring

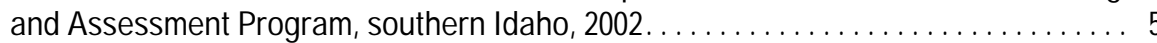

2. Fish species collected at all sites sampled for the Environmental M onitoring and

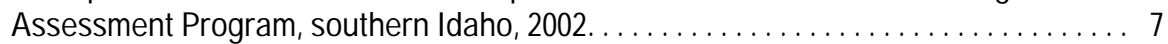

3. Fish metrics and nal Index of Biotic Integrity (IBI) scores, number of sh collected, total number of species, number of native species, and Zoogeographic Integrity Coef cient (ZIC) index values for all sites sampled for the Environmental M onitoring and Assessment Program, southern Idaho, 2002....................

4. Index of Biotic Integrity (IBI) scores and number of sh species and individuals collected at three sites in a reach length of 100 times the channel width sampled for the Environmental M onitoring and Assessment Program, southern Idaho, 2002 . . . . 13

\section{Conversion Factors and Datum}

\begin{tabular}{lll}
\hline Multiply & By & To obtain \\
\hline centimeter $(\mathrm{cm})$ & 0.3937 & inch (in.) \\
kilometer $(\mathrm{km})$ & 0.6214 & mile $(\mathrm{mi})$ \\
meter $(\mathrm{m})$ & 3.281 & foot $(\mathrm{ft})$ \\
millimeter $(\mathrm{mm})$ & 0.03937 & inch (in.) \\
\hline
\end{tabular}

To convert ${ }^{\circ} \mathrm{C}$ (degrees Celsius) to ${ }^{\circ} \mathrm{F}$ (degrees Fahrenheit), use the following equation:

$$
{ }^{\circ} \mathrm{F}=\left(1.8^{\circ} \mathrm{C}\right)+(32)
$$

Sea level: In this report, "sea level" refers to the National Geodetic Vertical Datum of 1929- a geodetic datum derived from a general adjustment of the rst-order level nets of the United States and Canada, formerly called Sea Level Datum of 1929. 


\title{
Assessment of Fish Assemblages and Minimum Sampling Effort Required to Determine Biotic Integrity of Large Rivers in Southern Idaho, 2002
}

\author{
By Terry R. Maret and Douglas S. Ott
}

\section{Abstract}

A critical issue surrounding biomonitoring in large rivers (fifth- through seventh-order) is the minimum sampling-reach distance required to collect an adequate number of fish to represent the fish assemblage within a reach. Excessive sampling effort (excessive reach length) is costly in terms of work hours, reduces the number of sites that can be visited, can compromise field-crew safety, can be logistically unfeasible, and can cause unnecessary injury to captured fish. On the other hand, inadequate sampling effort can produce considerable variability in multiple samples collected at a site and may underrepresent the species or river condition present.

During the summer of 2002, the U.S. Geological Survey, in cooperation with the Idaho Department of Environmental Quality, determined the minimum sampling effort required to characterize fish assemblages at 17 large-river sites in southern Idaho. The study was done as part of the U.S. Environmental Protection Agency's Environmental Monitoring and Assessment Program. Electrofishing methods and multiple gear types were used to collect sample populations of fish in river reach lengths representing 40 and 100 times the wetted channel width. Minimum sampling effort was assessed by comparing the relation between reach length and the number of species collected, total individuals collected, and final Index of Biotic Integrity (IBI) scores.

Thirty-two species of fish in the families Catostomidae, Centrarchidae, Cottidae, Cyprinidae, Ictaluridae, Percidae, and Salmonidae were collected. Of these, 12 alien species were collected, representing about 38 percent of all species collected during the study.

A reach length of 30 to 40 times the wetted channel width was determined to be sufficient for collecting an adequate number of fish to estimate species richness and evaluate biotic integrity. At most sites, about 250 fish were needed to effectively represent 95 percent of the species present. Fifty- three percent of the sites assessed, using an IBI developed specifically for large Idaho rivers, received scores of less than 50, indicating poor biotic integrity.

\section{Introduction}

Large rivers are the least ecologically understood and most poorly studied of any inland water resource and are perhaps the most affected by human activity (Dynesius and Nilsson, 1994; Simon and Sanders, 1999). Large-river investigations have been hampered by sampling difficulty and the lack of operational theoretical models related to conservation of biological resources (Reash, 1999; Galat and Zweimuller, 2001). The development of North America's rivers has supported many important human uses and needs, including navigation, flood control, hydropower, irrigation, waste disposal, and recreation. However, these uses have not come without a cost, especially in the depletion of native aquatic biodiversity and subsequent decline in native fish.

The primary causes for declines or extinctions of native fish include habitat alteration, pollution, hybridization, introduced species, and overharvest (Li and others, 1987; Miller and others, 1989). Many endemic fish species of the Western United States are endangered, threatened, or of special concern as a result of these human activities (Warren and Burr, 1994).

There are few published studies on large-river fish assemblages in Idaho. The fishery studies completed on the Snake River and its major tributaries are primarily agency reports assessing sportfishery populations (Maret, 1995). Idaho Power Company relicensing efforts have resulted in the compilation of anecdotal historical and recent data on fish species occurrences on the Snake River and its tributaries downstream from Shoshone Falls (Chandler and Radko, 2001). The U.S. Geological Survey (USGS) has provided recent (1993- 
2003) fishery data collected from a number of large rivers in Idaho as part of the National Water-Quality Assessment (NAWQA) Program and Statewide Surface-Water-Quality Trend Network to evaluate the status and trends of fish assemblages (data accessed at http://idaho.usgs.gov/ projects/fish/index.html).

As a result of the Clean Water Act's objective to "restore and maintain the physical, chemical, and biological integrity of the Nation's waters," more emphasis is being placed on development of biocriteria in State water-quality standards. Increasingly, biological monitoring programs and biocriteria development have expanded to include large rivers. The western U.S. Environmental Protection Agency (USEPA) Environmental Monitoring and Assessment Program (EMAP) recently has focused on evaluating ecological conditions of nonwadeable rivers; river conditions will be evaluated on the basis of a random site-selection design (Peck and others, 2002). The Index of Biotic Integrity (IBI) is used by many Federal and State agencies to assess fish assemblage structure and function because it serves as an indicator of historical and current conditions of a stream system (Karr, 1991). The Idaho Department of Environmental Quality (IDEQ) recently published monitoring protocols and an IBI that uses aquatic organisms and habitat measures to evaluate large rivers in Idaho (Grafe, 2002; Mebane and others, 2003). Zaroban and others (1999) classified Northwest fish species according to various attributes (for example, pollution sensitivity, temperature tolerance, feeding and habitat groups) to facilitate evaluation of surface-water resource conditions.

Regulatory agencies responsible for monitoring large numbers of waterbodies need consistent and cost-effective sampling methods for accurately and precisely measuring biotic integrity. A critical issue surrounding river biomonitoring is the minimum sampling-reach length required to adequately represent the fish assemblage. Because collection methods and sampling effort vary widely among national and State assessment programs (Flotemersch and Cormier, 2001), and because few studies have quantitatively evaluated the optimum electrofishing distance for large-river fisheries, no standard reach length currently is generally accepted. The NAWQA Program prescribes a sampling distance of 500 to $1,000 \mathrm{~m}$ for large rivers and the use of multiple gear (such as boat and backpack electrofishing) to more effectively sample different habitats within a representative reach (Meador and others, 1993). Hughes and others (2002) determined that a sampling distance of 85 to 100 times the average wetted channel width would be necessary to collect a sample population representing 95 percent of the fish species present in Oregon raftable rivers that were 10 to $150 \mathrm{~m}$ wide. However, their assessment did not evaluate the collection effort and the resulting IBI scores that are needed to determine aquatic life use support. On the basis of the Oregon study findings, the western USEPA EMAP protocols require a sampling reach length of 100 times the wetted channel width (100X) and use of boat electrofishing gear for large Western rivers (Peck and others, 2002). Given this requirement, sampling reaches can be longer than $10 \mathrm{~km}$, which could compromise the safety of the field crew, owing to an overextended workday. Also, because the sampling locations are chosen at random, these long reaches may not be logistically feasible to sample because of difficult access. In addition, electrofishing such long reach lengths could cause unnecessary injury to captured fish, especially to sensitive or federally listed species such as bull trout (Salvelinus confluentus) and chinook salmon (Oncorhynchus tshawytscha).

Geomorphology would be the primary determinant of sampling reach length and the associated instream habitats consisting of geomorphic channel units (for example, riffles, pools, and runs). Inclusion of at least one meander wavelength, based on 20X the wetted channel width (Leopold and others, 1964) in a sampling reach is necessary to ensure that representative habitats are sampled. These criteria are recommended for determining the length of sampling reach needed to represent fish assemblages (Lyons, 1992). In addition, the USEPA Rapid Bioassessment Protocols recommend sampling all habitats within a distance of $40 \mathrm{X}$ of boatable waters (Flotemersch and Cormier, 2001).

Hughes and others (2002) gave a number of reasons why sampling reaches consisting of 20 to $40 \mathrm{X}$ may not be adequate to effectively represent fish assemblages in large Western rivers. One of the reasons is that efficient collections in Western rivers may be compromised by swift water, more mobile fish, and hazardous obstructions. Evaluating the effects of electrofishing sampling effort is important to study design, development of site-scale sampling protocols, and quantification of ecological changes and patterns over time (Cao and others, 2002; Meador and others, 2003). Sampling distances that equal or exceed the threshold at which a desired attribute (such as species richness) becomes asymptotic are more likely to produce similar results than would additional sampling, which would yield comparatively little new information (Lyons, 1992). Excessive sampling effort is costly in terms of work hours and reduces the number of sites that can be visited, whereas inadequate sampling effort can produce considerable variability in multiple samples collected at a site and may underrepresent the species or river condition present.

\section{Purpose and Scope}

This report characterizes fish assemblages collected for the USEPA's EMAP in southern Idaho and identifies the minimum sampling effort (minimum reach length) required to collect a sample population of fish representing the greatest percentage of species within a reach. The data were collected at 17 sites in large (fifth- through seventh-order) rivers during the summer (July 25 through October 2) of 2002. Fish assemblages were characterized using various metrics that have proven beneficial for evaluating water-quality conditions in Idaho rivers. Minimum sampling effort was assessed by comparing the relation between reach length and the number of species collected, total individuals collected, and final IBI 
scores. This assessment will provide IDEQ with information on the status of the fisheries in southern Idaho and the level of effort necessary to provide fish assemblage data adequate to evaluate the biotic integrity of Idaho's large rivers.

\section{Description of Study Area}

The study area (fig. 1) comprises the main-stem Snake River and its major tributaries and the main-stem Salmon and Bear Rivers in southern Idaho. The study area is located primarily in the Snake River Basin/High Desert and Northern Basin and Range Ecoregions (Omernik and Gallant, 1986). The IDEQ has classified this area of Idaho as part of the Basins Bioregion on the basis of similarities in aquatic species and landscape features (Grafe, 2002).

Climate in most of the study area is semiarid and annual precipitation ranges from 25 to $50 \mathrm{~cm}$. Precipitation occurs primarily as snow, and peak flows generally result from spring snowmelt.

Range and forest land are the predominant land uses, and more than 60 percent of the land is federally owned. Populated areas and agricultural lands are located primarily adjacent to main-stem rivers and major tributaries to access water for irrigation and domestic supply purposes. Migrating fish face many obstacles along the Snake River. Shoshone Falls near Twin Falls, Idaho, is higher than Niagara Falls (more than 65 $\mathrm{m}$ high) and is a natural barrier to upstream movement of fish (fig. 1). Flow in the Snake River is highly regulated by dams and diversions. Eighteen large dams currently regulate the Snake River in the study area.

Most rivers in Idaho are presumed or explicitly designated to support coldwater biota (Grafe, 2002). Rivers in predominantly range and forest land basins of southern Idaho are typified by coarse substrate (gravel and cobbles), a variety of low- to high-gradient (0.01-1.0 percent) habitats, and generally sparse macrophyte growth. Rivers in agricultural basins are typified by more fine-grained substrate, low-gradient habitats, and abundant macrophyte growth. Wetted channel widths ranged from about 8 to $193 \mathrm{~m}$ at all sampling sites, excluding site 8 , which was almost dry at the time of sampling (table 1). Sampling site elevation above sea level ranged from 670 to $1,850 \mathrm{~m}$. Because of drought conditions, southern Idaho river flows were about 60 to 80 percent of the long-term average during the sampling period (Brennan and others, 2003).

\section{Acknowledgments}

Numerous individuals from the USGS assisted in collecting and processing data during the course of this study: Ross G. Dickinson, Jon E. Hortness, Dorene E. MacCoy, Michael A. Nolevanko, Robert E. Reaves, and Kenneth D. Skinner. Sean Woodhead of IDEQ assisted with fish sampling at the Rock Creek site. Colleague reviews by William $\mathrm{H}$. Clark, Cyndi S. Grafe, Dorene E. MacCoy, Michael R. Mea- dor, and Christopher A. Mebane improved the quality of the manuscript. Special thanks are extended to Donald W. Zaroban for assisting with the identification and vouchering of fish specimens and to Robert E. Hughes and Philip R. Kaufman for their help in training field crews in sampling methods. Funding for this work was provided by the USGS and the IDEQ.

\section{Methods}

\section{Site Selection}

Sites selected for sampling were provided by the IDEQ. Site selection was based on a random selection process of Idaho rivers in the Basins Bioregion of southern Idaho that were equal to or greater than fifth order on 1:100,000-scale hydrographic maps (C.S. Grafe, Idaho Department of Environmental Quality, written commun., 2002). About 50 candidate sites representing a diverse set of river sizes and physical and chemical habitats were selected. About 10 sites were eliminated immediately from this list for reasons related primarily to safety and access. The Snake River at Heise (site 1) was hand selected (HSSD) to represent a main-stem Snake River reference site that was not in the original random list provided. Field reconnaissance of the remaining 40 sites by USGS and IDEQ resulted in 17 sites (fig. 1 and table 1) selected for sampling that met the criteria given by Grafe (2002) and Peck and others (2002). Other biological and habitat data were collected concurrently by IDEQ at all sites but are not summarized in this report.

\section{Fish Collection and Processing}

Fish were collected at 17 large-river sites during lowflow conditions (July 25 through October 2) in 2002 following USEPA EMAP protocols (Peck and others, 2002, table 1). All collections and identifications were made by USGS personnel using a team of scientists familiar with fish species of Idaho. All personnel involved with fish sampling were trained in electrofishing techniques and EMAP sampling protocols. Fourteen reaches that included one duplicate reach (total of 13 sites) were electrofished over a reach length representing $40 \mathrm{X}$ (Peck and others, 2001). Three sites were electrofished at a reach length representing $100 \mathrm{X}$ to evaluate information gained by additional sampling effort (Peck and others, 2002): Snake River at Heise, Snake River near Marsing, and Payette River near Emmett. The Big Lost River above Mackay Reservoir (site 8) was intermittent, resulting in an assessed reach length of about $15 \mathrm{~m}$. For this reason, this site was not included in any of the final data assessments. All reaches sampled were divided into 10 continuous subreaches of equal length (noted as A through $\mathrm{J}$ ). The data for each subreach were recorded separately to calculate statistical relations between sampling 


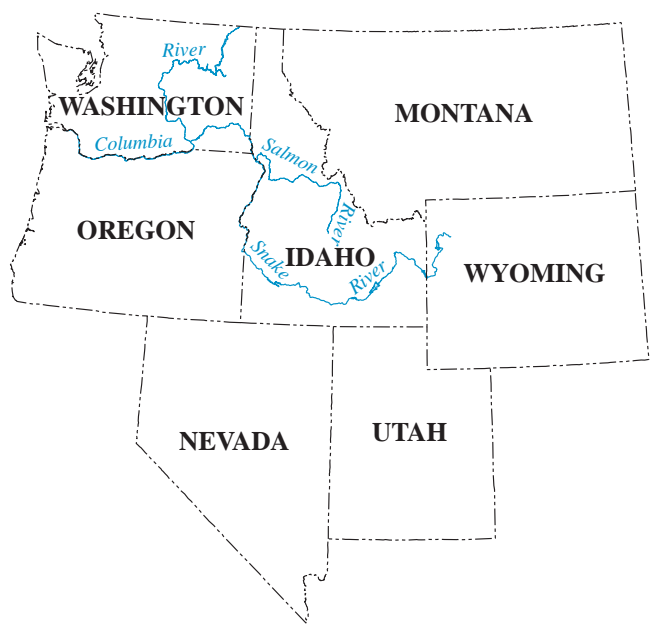

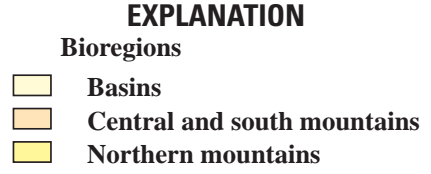

- EMAP sampling sites

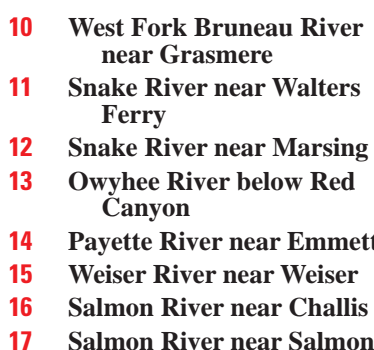

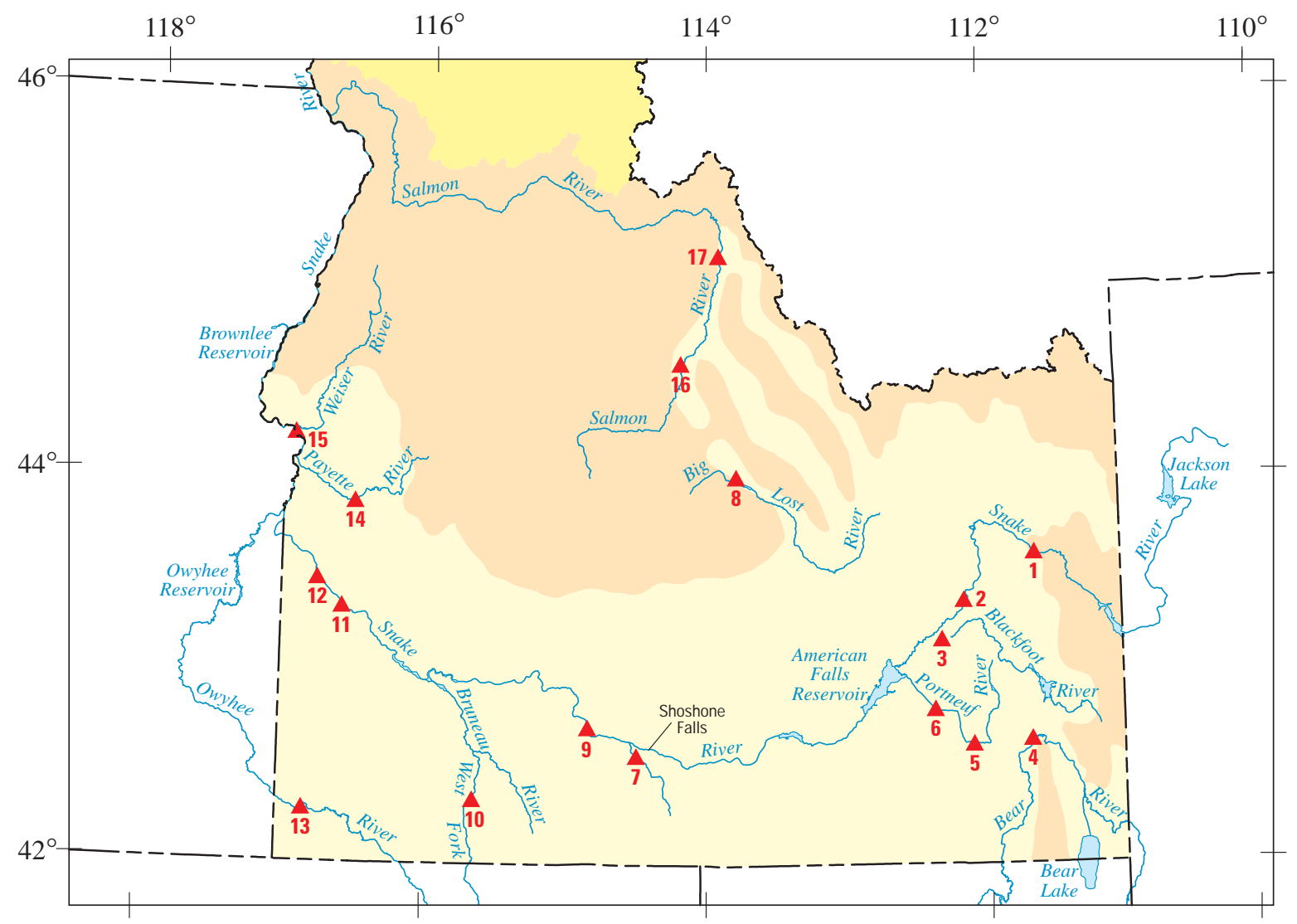

Base from U.S. Geological Survey digital data; 1972; 1:2,000,000,

Transverse M ercator projection; Factor at central meridian: 0.99960;

Longitude of central meridian: $-114^{\circ} 00^{\prime}$; Latitude of origin: $42^{\circ} 00^{\prime}$

False easting (meters): 500,000; False northing (meters): 100,000

Bioregions modified from U.S. Environmental Protection Agency

digital data; Region 10 Ecoregions; 1991; 1:2,000,000

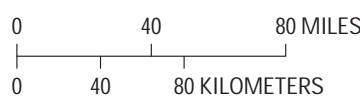

Figure 1. Location of study area, Environmental M onitoring and Assessment Program (EM AP) sampling sites, and bioregions in southern Idaho, 2002. 
Table 1. Basin and site characteristics for all sites sampled for the Environmental Monitoring and Assessment Program(EMAP), southern Idaho, 2002

[Site locations shown in figure 1; no., number; ID, identification; m, meters; HSSD, hand selected]

\begin{tabular}{|c|c|c|c|c|c|c|c|c|c|c|}
\hline Site no. & Site name & $\begin{array}{l}\text { EMAP } \\
\text { site ID }\end{array}$ & Latitude & Longitude & $\begin{array}{c}\text { Stream } \\
\text { order }\end{array}$ & $\begin{array}{l}\text { Elevation } \\
\text { (m above } \\
\text { sea level) }\end{array}$ & $\begin{array}{l}\text { Average } \\
\text { wetted } \\
\text { channel } \\
\text { width } \\
\text { (m) }\end{array}$ & $\begin{array}{l}\text { Reach } \\
\text { length } \\
(\mathrm{m})\end{array}$ & $\begin{array}{l}\text { Electro- } \\
\text { fishing } \\
\text { gear type }\end{array}$ & $\begin{array}{l}\text { Electrofishing } \\
\text { time } \\
\text { (seconds/ } \\
\text { hours) }\end{array}$ \\
\hline${ }^{1} 1$ & Snake River at Heise $\ldots \ldots \ldots \ldots \ldots \ldots \ldots \ldots \ldots \ldots$ & HSSD & $43^{\circ} 35^{\prime} 48^{\prime \prime}$ & $111^{\circ} 36^{\prime} 59^{\prime \prime}$ & 6 & 1,530 & 110 & 11,000 & raft & $7,051 / 1.96$ \\
\hline 2 & Snake River near Shelley $\ldots \ldots \ldots \ldots \ldots \ldots \ldots \ldots \ldots$ & 29 & $43^{\circ} 22^{\prime} 10^{\prime \prime}$ & $112^{\circ} 10^{\prime} 02^{\prime \prime}$ & 6 & 1,400 & 130 & 5,200 & raft & $3,466 / 0.96$ \\
\hline 3 & Blackfoot River near Blackfoot. ..................... & 9 & $43^{\circ} 10^{\prime} 04^{\prime \prime}$ & $112^{\circ} 19^{\prime} 34^{\prime \prime}$ & 6 & 1,350 & 18 & 720 & raft & $2,215 / 0.62$ \\
\hline 4 & Bear River below Alexander Reservoir near Soda Springs ..... & 37 & $42^{\circ} 38^{\prime} 45^{\prime \prime}$ & $111^{\circ} 41^{\prime} 56^{\prime \prime}$ & 5 & 1,720 & 40 & 1,600 & raft & $1,588 / 0.44$ \\
\hline 5 & Portneuf River near Topaz. & 130 & $42^{\circ} 37^{\prime} 25^{\prime \prime}$ & $112^{\circ} 06^{\prime} 37^{\prime \prime}$ & 5 & 1,500 & 15 & 600 & raft & $1,113 / 0.31$ \\
\hline 6 & Portneuf River near Pocatello . ..................... & 70 & $42^{\circ} 48^{\prime} 24^{\prime \prime}$ & $112^{\circ} 22^{\prime} 47^{\prime \prime}$ & 5 & 1,350 & 12 & 480 & raft & $1,226 / 0.34$ \\
\hline 7 & Rock Creek at Twin Falls $\ldots \ldots \ldots \ldots \ldots \ldots \ldots \ldots$ & 1 & $42^{\circ} 33^{\prime} 19^{\prime \prime}$ & $114^{\circ} 28^{\prime} 51^{\prime \prime}$ & 5 & 1,100 & 8 & 320 & tote barge & $1,627 / 0.45$ \\
\hline 27 & Rock Creek at Twin Falls $\ldots \ldots \ldots \ldots \ldots \ldots \ldots \ldots$ & 1 & $42^{\circ} 33^{\prime} 36^{\prime \prime}$ & $114^{\circ} 29^{\prime} 37^{\prime \prime}$ & 5 & 1,100 & 8 & 320 & tote barge & $1,579 / 0.44$ \\
\hline${ }^{3} 8$ & Big Lost River above Mackay Reservoir near Mackay........ . & 17 & $44^{\circ} 00^{\prime} 36^{\prime \prime}$ & $113^{\circ} 47^{\prime} 11^{\prime \prime}$ & 5 & 1,850 & 3 & 15 & backpack & $45 / 0.01$ \\
\hline 9 & Snake River at Hagerman $\ldots \ldots \ldots \ldots \ldots \ldots \ldots \ldots$ & 50 & $42^{\circ} 42^{\prime} 35^{\prime \prime}$ & $114^{\circ} 50^{\prime} 24^{\prime \prime}$ & 7 & 880 & 193 & 7,700 & jet boat & $6,438 / 1.79$ \\
\hline 10 & West Fork Bruneau River near Grasmere $\ldots \ldots \ldots \ldots \ldots \ldots$ & 77 & $42^{\circ} 20^{\prime} 02^{\prime \prime}$ & $115^{\circ} 38^{\prime} 52^{\prime \prime}$ & 5 & 1,140 & 14 & 560 & backpack & $1,724 / 0.48$ \\
\hline 11 & Snake River near Walters Ferry .................... & 115 & $43^{\circ} 19^{\prime} 49^{\prime \prime}$ & $116^{\circ} 35^{\prime} 40^{\prime \prime}$ & 7 & 700 & 130 & 5,200 & jet boat & $3,127 / 0.87$ \\
\hline${ }^{1} 12$ & Snake River near Marsing. & 26 & $43^{\circ} 28^{\prime} 27^{\prime \prime}$ & $116^{\circ} 46^{\prime} 30^{\prime \prime}$ & 7 & 680 & 150 & 15,000 & jet boat & $13,764 / 3.82$ \\
\hline 1,412 & Snake River near Marsing ........... & 26 & $43^{\circ} 28^{\prime} 27^{\prime \prime}$ & $116^{\circ} 46^{\prime} 30^{\prime \prime}$ & 7 & 680 & 150 & 15,000 & jet boat & $8,464 / 2.35$ \\
\hline 13 & Owyhee River below Red Canyon. . .................. & 32 & $42^{\circ} 16^{\prime} 37^{\prime \prime}$ & $116^{\circ} 50^{\prime} 29^{\prime \prime}$ & 5 & 1,340 & 22 & 880 & backpack & $2,729 / 0.76$ \\
\hline${ }^{1} 14$ & Payette River near Emmett $\ldots \ldots \ldots \ldots \ldots \ldots \ldots \ldots$ & 131 & $43^{\circ} 52^{\prime} 34^{\prime \prime}$ & $116^{\circ} 31^{\prime} 08^{\prime \prime}$ & 6 & 720 & 60 & 6,000 & raft & $4,681 / 1.30$ \\
\hline 15 & Weiser River near Weiser. . ....................... & 103 & $44^{\circ} 14^{\prime} 54^{\prime \prime}$ & $116^{\circ} 57^{\prime} 31^{\prime \prime}$ & 6 & 670 & 25 & 1,000 & raft & $2,088 / 0.58$ \\
\hline 16 & Salmon River near Challis.................. & 79 & $44^{\circ} 36^{\prime} 00^{\prime \prime}$ & $114^{\circ} 11^{\prime} 10^{\prime \prime}$ & 6 & 1,490 & 40 & 1,600 & raft & $1,315 / 0.37$ \\
\hline 17 & Salmon River near Salmon $\ldots \ldots \ldots \ldots \ldots \ldots \ldots \ldots$ & 92 & $45^{\circ} 09^{\prime} 35^{\prime \prime}$ & $113^{\circ} 54^{\prime} 48^{\prime \prime}$ & 6 & 1,190 & 50 & 2,000 & raft & $1,941 / 0.54$ \\
\hline
\end{tabular}

${ }^{1}$ Reach sampled at 100 times the wetted channel width.

${ }^{3}$ Channel composed of intermittent pools.

${ }^{2}$ Spatial duplicate.

${ }^{4}$ Temporal duplicate. 
effort and species collection. A Global Positioning System and laser range finder were used to determine sampling locations. All sampling was limited to 1 day per site, which included both travel and collection time. Total collection time in the field to sample reach lengths of 30 to $40 \mathrm{X}$ was about 3 to 6 hours and, to sample reach lengths of $100 \mathrm{X}$, was about 10 to 14 hours.

The selection of electrofishing methods depended primarily on river access and size (width and depth of channel). Electrofishing was concentrated near the riverbanks. Where possible, after two consecutive subreaches were sampled, collections were alternated to the opposite bank. This ensured that habitats from both banks were sampled throughout the reach. Collection methods attempted to capture all fish species from habitats at each sampling site.

Because of the wide variety of field conditions encountered, four electrofishing gear types were used for a single pass through a reach (see table 1 for gear type used for each site). These included backpack ( 3 sites), tote barge (1 site), raft (10 sites), and jet boat (3 sites). Backpack and tote barge collections were made in an upstream direction to most effectively capture fish encountered. The backpack unit (SmithRoot model 12) and the tote barge (Smith-Root model VI-A, direct current (DC) pulsator and 5,000-watt, 240-volt generator) both were operated with one anode and one netter. The raft and jet boat also were equipped with a Smith-Root model VI-A, DC pulsator and a 5,000-watt, 240-volt generator with one or two bow-mounted anode electrodes made of a circular array of 6.5-mm steel cable extending in front of the bow. The jet boat hull served as the cathode, and an array of aluminum conduit composed the port and starboard cathode droppers on the raft. Fish collections from the raft and jet boat were made while the vessel floated in a downstream direction and one netter was positioned in the bow of the boat. When large numbers of easily identifiable fish, for example, common carp (Cyprinus carpio) and largescale suckers (Catostomus macrocheilus), were too numerous to net while boat electrofishing, they were tallied visually. The motorized jet boat was particularly useful at low-gradient sites where wind inhibited floating in a downstream direction. There was no effort to concentrate extra sampling effort at specific habitat types while floating (riffles, pools, woody snags, etc.). Electrofishing DC usually varied between 30 and 60 pulses per second and 400 to 1,000 volts, depending on conductivity of the water. Electrofishing time ranged from 0.3 to 1.8 hours for sites sampled at $40 \mathrm{X}$, except site 8 , which consisted of a few intermittent pools. Electrofishing time for the three sites sampled at 100X ranged from 1.3 to 3.8 hours.

Captured fish were placed in an aerated livewell and processed immediately after sampling each subreach to reduce stress to the fish. When necessary, fish were anesthetized with a dilute solution of clove oil and ethanol. All fish were identified to species, counted, and measured (minimum and maximum total length). The presence of external anomalies (deformities, eroded fins, lesions, and tumors) also was recorded. Specimens of selected species were retained for reference and verification of field identifications. Species too large for collection jars were photographed before being returned to the river. A voucher collection from these samples is located in the Orma J. Smith Museum of Natural History, Albertson College, Caldwell, Idaho. Prior to sampling, an Idaho Department of Fish and Game scientific collection permit, number F-18-87, was obtained by William H. Clark of IDEQ. Donald W. Zaroban, fish curator for the Orma J. Smith Museum of Natural History, provided taxonomic confirmation for selected specimens. For calculation of the IBI, rainbow trout (Oncorhynchus mykiss) were considered alien upstream from Shoshone Falls, which historically limited their upstream distribution in the Columbia and Snake River system (Behnke, 1992). Where distinguishable, hatchery fish were excluded from IBI calculations (Mebane and others, 2003).

Two sites were selected for duplicate sampling to evaluate spatial and temporal variability in collection methods. At Rock Creek at Twin Falls (site 7), fish were collected during the same week on different reaches of equal length that were about $2 \mathrm{~km}$ apart. At the Snake River near Marsing (site 12), fish were collected on the same reach at the beginning and end of the sampling period.

\section{Analytical Methods (See Errata on Inside Cover)}

Fish assemblages were analyzed using abundances of individuals and species and an IBI developed by Mebane and others (2003). Geographic origin (native or alien), tolerance to pollution, and temperature preferences were assigned to each species (table 2) following guidelines outlined by Zaroban and others (1999). General tolerances and temperature preferences were gleaned from reference literature and from the authors' experience in observing how species distributions and abundances changed with increased temperatures, turbidity, sedimentation, and nutrient concentrations.

The IBI developed specifically for evaluating conditions of large rivers in the Pacific Northwest (table 3) consists of 10 metrics: number of coldwater native species, number of cottid age classes, percent sensitive native individuals, percent coldwater individuals, percent tolerant individuals, number of alien species, percent common carp individuals, number of salmonid age classes, catch per unit effort (fish captured per minute of electrofishing), and percent selected anomalies (deformities, eroded fins, lesions, and tumors). Because only minimum and maximum lengths are required for EMAP, number of cottid and salmonid age classes could not be determined accurately; therefore, these two metrics were not used. However, as suggested by Mebane and others (2003), percent sculpins can be substituted for number of cottid age classes in the IBI calculations. These nine metrics were standardized by scoring them continuously from 0 to 1 , then weighted as necessary to produce an IBI score ranging from 0 to 100 . According to Mebane and others (2003), sites with IBI scores between 75 and 100 exhibit high biotic integrity and minimal disturbance and support an abundant and diverse assemblage 
Table 2. Fish species collected at all sites sampled for the Environmental M onitoring and Assessment Program, southern Idaho, 2002

[Assignment of geographic origin, tolerance to pollution, and temperature preference of fish were taken from Zaroban and others (1999); sites of occurrence shown in figure 1 and described in table 1]

\begin{tabular}{|c|c|c|c|c|c|}
\hline $\begin{array}{l}\text { Family } \\
\text { Common name }\end{array}$ & Species & Origin $^{1}$ & $\begin{array}{c}\begin{array}{c}\text { Tolerance } \\
\text { to }\end{array} \\
\text { pollution }^{2}\end{array}$ & $\begin{array}{l}\text { Temperature } \\
\text { preference }\end{array}$ & Sites of occurrence \\
\hline \multicolumn{6}{|l|}{ Catostomidae } \\
\hline bluehead sucker & Catostomus discobolus & $\mathrm{N}$ & I & cool & 2,6 \\
\hline bridgelip sucker ${ }^{3}$ & Catostomus columbianus & $\mathrm{N}$ & $\mathrm{T}$ & cool & $7,10,11,12,14,15,16,17$ \\
\hline largescale sucker ${ }^{3}$ & Catostomus macrocheilus & $\mathrm{N}$ & $\mathrm{T}$ & cool & $\begin{array}{l}7,9,10,11,12,13,14,15,16 \\
17\end{array}$ \\
\hline mountain sucker & Catostomus platyrhynchus & $\mathrm{N}$ & I & cool & $5,10,14,17$ \\
\hline Utah sucker & Catostomus ardens & $\mathrm{N}$ & $\mathrm{T}$ & cool & $1,2,3,4,6$ \\
\hline \multicolumn{6}{|l|}{ Centrarchidae } \\
\hline black crappie & Pomoxis nigromaculatus & $\mathrm{A}$ & $\mathrm{T}$ & warm & 12,15 \\
\hline bluegill & Lepomis macrochirus & A & $\mathrm{T}$ & warm & 15 \\
\hline largemouth bass & Micropterus salmoides & A & $\mathrm{T}$ & warm & 15 \\
\hline pumpkinseed & Lepomis gibbosus & A & $\mathrm{T}$ & cool & 15 \\
\hline smallmouth bass & Micropterus dolomieui & A & I & cool & $11,12,13,14,15$ \\
\hline white crappie & Pomoxis annularis & A & $\mathrm{T}$ & warm & 15 \\
\hline \multicolumn{6}{|l|}{ Cottidae } \\
\hline mottled sculpin & Cottus bairdi & $\mathrm{N}$ & I & cold & $1,2,3,4,5,6,7,10,13,16,17$ \\
\hline Paiute sculpin & Cottus beldingi & $\mathrm{N}$ & I & cold & $1,2,6,13$ \\
\hline shorthead sculpin ${ }^{3}$ & Cottus confusus & $\mathrm{N}$ & $S$ & cold & 14,16 \\
\hline \multicolumn{6}{|l|}{ Cyprinidae } \\
\hline common carp & Cyprinus carpio & A & $\mathrm{T}$ & warm & $2,3,4,5,6,7,9,11,12,14,15$ \\
\hline chiselmouth $^{3}$ & Acrocheilus alutaceus & $\mathrm{N}$ & I & cool & $7,10,11,12,13,14,15,16$ \\
\hline fathead minnow & Pimephales promelas & A & $\mathrm{T}$ & warm & 2 \\
\hline leatherside chub & Gila copei & $\mathrm{N}$ & I & cool & 3 \\
\hline longnose dace & Rhinichthys cataractae & $\mathrm{N}$ & I & cool & $1,2,3,6,10,13,14,15,16,17$ \\
\hline northern pikeminnow ${ }^{3}$ & Ptychocheilus oregonensis & $\mathrm{N}$ & $\mathrm{T}$ & cool & $9,10,11,12,14,15,16,17$ \\
\hline peamouth $^{3}$ & Mylocheilus caurinus & $\mathrm{N}$ & I & cool & 12 \\
\hline redside shiner & Richardsonius balteatus & $\mathrm{N}$ & I & cool & $2,3,4,5,6,7,9,10,17$ \\
\hline
\end{tabular}


Table 2. Fish species collected at all sites sampled for the Environmental Monitoring and Assessment Program, southern Idaho, 2002Continued

\begin{tabular}{|c|c|c|c|c|c|}
\hline $\begin{array}{l}\text { Family } \\
\text { Common name }\end{array}$ & Species & Origin $^{1}$ & $\begin{array}{c}\begin{array}{c}\text { Tolerance } \\
\text { to }\end{array} \\
\text { pollution }^{2}\end{array}$ & $\begin{array}{l}\text { Temperature } \\
\text { preference }\end{array}$ & Sites of occurrence \\
\hline \multicolumn{6}{|l|}{ Cyprinidae-Continued } \\
\hline speckled dace & Rhinichthys osculus & $\mathrm{N}$ & I & cool & $1,2,3,4,5,6,7,10,16,17$ \\
\hline Utah chub & Gila atraria & $\mathrm{N}$ & $\mathrm{T}$ & cool & $3,7,9$ \\
\hline \multicolumn{6}{|l|}{ Ictaluridae } \\
\hline channel catfish & Ictalurus punctatus & A & $\mathrm{T}$ & warm & $11,12,14,15$ \\
\hline tadpole madtom & Noturus gyrinus & A & $\mathrm{T}$ & warm & 15 \\
\hline \multicolumn{6}{|l|}{ Percidae } \\
\hline yellow perch & Perca flavescens & A & I & cool & $4,11,12$ \\
\hline \multicolumn{6}{|l|}{ Salmonidae } \\
\hline brown trout & Salmo trutta & A & I & cold & $1,2,5,6,7$ \\
\hline chinook salmon 3,4 & Oncorhynchus tshawytscha & $\mathrm{N}$ & S & cold & 16 \\
\hline cutthroat trout $^{5}$ & Oncorhynchus clarki & $\mathrm{N}$ & $S$ & cold & 1,2 \\
\hline mountain whitefish & Prosopium williamsoni & $\mathrm{N}$ & I & cold & $1,2,8,9,10,14,16,17$ \\
\hline rainbow trout ${ }^{3}$ & Oncorhynchus mykiss & $\mathrm{N}$ & S & cold & $1,2,6,7,9,16,17$ \\
\hline
\end{tabular}

of native coldwater species; sites with scores between 50 and 74 exhibit moderate biotic integrity where alien species are more frequent and the assemblage is dominated by coolwater, native species; sites with scores $<50$ exhibit poor biotic integrity where coldwater and sensitive species are rare or absent and where tolerant fish predominate. For a more detailed description of index development, metric response, and application, see the report by Mebane and others (2003).

Major faunal shifts in many streams in the Western United States are the result of alien fish species. Often, alien fish species are better adapted than native species to thrive in altered habitats (Moyle, 1994). The status of fish assemblages is related to the extent of habitat disturbance and the occurrence of native versus alien species. The Zoogeographic Integrity Coefficient (ZIC) index, derived from the ratio of the number of native species to the total number of species, was used to evaluate the degree of habitat disturbance, whereby a value of 1 indicates an undisturbed environment and a value of 0 indicates a highly disturbed environment (Elvira, 1995).

Various statistical relations between sampling effort and species collection were calculated to evaluate information gained from additional collection effort in successive subreaches. At the three sites sampled at 100X, all possible combinations of four contiguous subreaches (total of seven possible combinations) totaling $40 \mathrm{X}$ were assessed and compared with results for the entire reach. These comparisons were useful for evaluating whether additional collection effort beyond 40X would change the overall assessment of biotic integrity. All statistical and graphical analyses were performed using SYSTAT (Wilkinson, 1999). Significant differences between medians of sample groups were determined with the nonparametric Mann-Whitney t-test. Differences were considered statistically significant when $\mathrm{p}<0.05$. 
Table 3. Fish metrics and final Index of Biotic Integrity (IBI) scores, number of fish collected, total number of species, number of native species, and Zoogeographic Integrity Coefficient (ZIC) index values for all sites sampled for the Environmental Monitoring and Assessment Program, southern Idaho, 2002

[No., number; TFF, too few fish to calculate index score]

In the row labeled "Final IBI score," all values should be divided by $0.9(9 / 10)$ to be comparable with IBI scores described in Mebane and others, 2003. See Errata, inside cover.

\begin{tabular}{|c|c|c|c|c|c|c|c|c|c|c|c|c|c|c|c|c|c|c|c|}
\hline \multirow{3}{*}{ Metrics } & \multicolumn{19}{|c|}{ Site No. ${ }^{1}$} \\
\hline & 1 & 2 & 3 & 4 & 5 & 6 & 7 & 27 & 8 & 9 & 10 & 11 & 12 & ${ }^{3} 12$ & 13 & 14 & 15 & 16 & 17 \\
\hline & \multicolumn{19}{|c|}{ IBI scores } \\
\hline $\begin{array}{l}\text { No. of coldwater native } \\
\text { species.............. }\end{array}$ & 4 & 4 & 1 & 1 & 1 & 2 & 2 & 2 & 1 & 2 & 2 & 0 & 0 & 0 & 2 & 2 & 0 & 5 & 3 \\
\hline Percent sculpin . . . . . . . & 3.0 & 6.0 & 7.0 & 4.0 & 1.0 & 6.0 & 9.0 & 18.0 & 0.0 & 0.0 & 7.0 & 0.0 & 0.0 & 0.0 & 16.0 & 1.0 & 0.0 & 4.0 & 2.0 \\
\hline $\begin{array}{l}\text { Percent sensitive native } \\
\text { individuals........... }\end{array}$ & 12.0 & 1.0 & 0.0 & 0.0 & 0.0 & 0.0 & 2.0 & 15.0 & 0.0 & 0.0 & 0.0 & 0.0 & 0.0 & 0.0 & 0.0 & 1.0 & 0.0 & 7.0 & 1.0 \\
\hline $\begin{array}{c}\text { Percent coldwater } \\
\text { individuals. . . . . }\end{array}$ & 98.0 & 21.0 & 7.0 & 4.0 & 2.0 & 7.0 & 35.0 & 61.0 & 100 & 1.0 & 9.0 & 0.0 & 0.0 & 0.0 & 16.0 & 17.0 & 0.0 & 62.0 & 33.0 \\
\hline $\begin{array}{c}\text { Percent tolerant } \\
\text { individuals... }\end{array}$ & 1.0 & 26.0 & 52.0 & 24.0 & 28.0 & 62.0 & 31.0 & 24.0 & 0.0 & 94.0 & 25.0 & 52.0 & 69.0 & 47.0 & 2.0 & 41.0 & 35.0 & 31.0 & 45.0 \\
\hline No. of alien species ..... & 2 & 4 & 1 & 2 & 2 & 3 & 2 & 1 & 0 & 1 & 0 & 4 & 4 & 4 & 1 & 3 & 9 & 0 & 0 \\
\hline $\begin{array}{l}\text { Percent common carp } \\
\text { individuals.......... }\end{array}$ & 0.0 & 0.3 & 12.2 & 14.2 & 28.3 & 0.8 & 0.4 & 0.0 & 0.0 & 1.5 & 0.0 & 18.1 & 35.7 & 12.1 & 0.0 & 6.6 & 2.4 & 0.0 & 0.0 \\
\hline Catch per unit effort ${ }^{4}$ & 8.7 & 1.3 & 0.3 & 0.5 & 0.3 & 1.3 & 3.3 & 5.5 & 4.0 & 0.1 & 0.7 & 0.0 & 0.0 & 0.0 & 0.4 & 1.6 & 0.0 & 8.5 & 2.9 \\
\hline $\begin{array}{l}\text { Percent selected } \\
\text { anomalies }{ }^{5} \ldots\end{array}$ & 0.0 & 0.0 & 0.6 & 0.8 & 0.0 & 0.0 & 0.4 & 2.5 & 0.0 & 0.0 & 0.0 & 0.2 & 1.1 & 0.0 & 0.9 & 0.0 & 2.4 & 0.0 & 0.4 \\
\hline Final IBI score & 69 & 51 & 23 & 27 & 27 & 34 & 55 & 67 & TFF & 20 & 56 & 10 & 5 & 13 & 51 & 32 & 11 & 73 & 56 \\
\hline \multicolumn{20}{|l|}{ Other metrics } \\
\hline No. of fish collected..... & 1,050 & 358 & 164 & 394 & 304 & 358 & 260 & 241 & 3 & 581 & 214 & 409 & 356 & 967 & 109 & 692 & 82 & 300 & 283 \\
\hline No. of native species .... & 7 & 8 & 7 & 4 & 4 & 6 & 6 & 8 & 1 & 6 & 10 & 4 & 5 & 3 & 5 & 7 & 5 & 10 & 10 \\
\hline Total no. of species ..... & 9 & 13 & 8 & 6 & 6 & 10 & 9 & 9 & 1 & 7 & 10 & 8 & 9 & 7 & 6 & 10 & 14 & 10 & 10 \\
\hline $\mathrm{ZIC}^{6}$. & 0.78 & 0.62 & 0.88 & 0.67 & 0.67 & 0.60 & 0.67 & 0.89 & TFF & 0.71 & 1.00 & 0.50 & 0.56 & 0.43 & 0.83 & 0.73 & 0.36 & 1.00 & 1.00 \\
\hline
\end{tabular}




\section{Results of Fish Assemblages}

Thirty-two species of fish in the families Catostomidae, Centrarchidae, Cottidae, Cyprinidae, Ictaluridae, Percidae, and Salmonidae were collected (table 2). Twelve alien species representing about 38 percent of all species were collected. Many of these alien species such as sunfish (Centrarchidae), common carp (Cyprinidae), and catfish (Ictaluridae) are adapted for warmwater habitats, especially those habitats created by impoundments. The most commonly collected species (collected at 10 or more sites) were largescale sucker, mottled sculpin, common carp, longnose dace, and speckled dace. Common carp, a tolerant alien, was collected at about 65 percent (11 of 17) of the sites. According to Mebane and others (2003), the presence of carp indicates degraded conditions in Pacific Northwest rivers.

The presence of smallmouth bass, an alien piscivore, in the Snake River (sites 11 and 12), Owyhee River (site 13), and Payette and lower Weiser Rivers (sites 14 and 15) indicates a potential hazard to native fish such as cyprinids, cottids, and juvenile salmonids. Miller and others (1989) indicated that alien fish species were a factor in 68 percent of North American fish extinctions. Hughes and others (2002) also noted this concern about the widespread occurrence of smallmouth bass in many rivers in Oregon. The presence of channel catfish, a warmwater-adapted species, also indicates that these river reaches no longer offer coldwater habitat for many native fish. Small native benthic fish (sculpins and dace) commonly were collected with boat electrofishing, although the abundances of these species likely were underrepresented by jet boat or raft electrofishing. For example, the percent sculpins collected by jet boat or raft never exceeded 7 percent at any site (table 3 ). Mebane and others (2003) found that the percent sculpins collected by multiple gear (raft and backpack electrofisher) at six sites on the Salmon River, a minimally disturbed large river in Idaho, averaged about 30 percent.

The number of fish collected at all sites (excluding site 8) ranged from 82 to 1,050 (table 3). Only three mountain whitefish were collected from the Big Lost River above Mackay Reservoir (site 8). This site was almost dry; only a few intermittent pools remained.

Two relatively rare species were collected-bluehead suckers at the Snake River near Shelley (site 2) and Portneuf River near Pocatello (site 6), and a leatherside chub at Blackfoot River near Blackfoot (site 3). Federally listed chinook salmon juveniles were collected only from the Salmon River near Challis (site 16).

\section{Fish Metrics and Index Scores}

Final IBI scores for all sites ranged from 5 (Snake River near Marsing, site 12) to 73 (Salmon River near Challis, site
16) (table 3). The unusually low IBI scores for the Snake River near Marsing and Walters Ferry (site 11) likely were due to recent fish kills as a result of excessively high water temperatures (J.C. Dillon, Idaho Department of Fish and Game, oral commun., 2002). IBI scores for about 53 percent (9 of 16) of the sites, excluding site 8 with only 3 fish, were $<50$, indicating poor biotic integrity (Mebane and others, 2003). Typically, few or no coldwater or sensitive species were collected at these sites, and the assemblage was composed predominately of tolerant cool or warmwater species. Although analysis of human factors responsible for these poor biotic conditions is beyond the scope of this study, reports by Maret $(1995,1997)$ summarize land and water uses affecting fish populations in southern Idaho. No sites sampled during this study received high IBI scores (>75). Sites where salmonids were collected may have received a slightly higher IBI score if age classes had been determined. Distinguishing salmonid age classes for future EMAP assessments would more fully utilize the IBI developed for Idaho rivers.

The Weiser River near Weiser (site 15) received the lowest ZIC index value of 0.36 and one of the lowest IBI scores (11), indicating a highly disturbed environment. The highest total number of species (14) was collected at this site; however, only 5 of these species were native. Most of the species collected at this site were warmwater-adapted aliens such as black crappie, white crappie, bluegill, largemouth bass, common carp, channel catfish, and tadpole madtom. West Fork Bruneau River near Grasmere (site 10) and the two Salmon River sites (16 and 17) received high ZIC index values of 1.0, indicating no habitat disturbance. These same sites also received some of the highest IBI scores, ranging from 56 to 73.

\section{Sampling Effort}

On the basis of 14 reaches sampled at 40X, fish collected in an average of 7.5 subreaches ( 30 channel widths) represented about 95 percent of the species present in the entire reach (fig. 2). Collections in three different reaches sampled at $100 \mathrm{X}$ also supported this finding. Few, if any, additional species were collected after sampling 30 to $40 \mathrm{X}$ (three to four subreaches) the channel width at those sites representing 100X (fig. 3). One additional species, a longnose dace, was collected in the last subreach in the Snake River at Heise (site 1). As expected, the asymptote was reached after minimum sampling effort (30 to 40X) at reaches characterized by few species, homogeneous physical habitat, and slow velocities (for example, Snake River near Marsing, site 12). Contrary to these findings, Hughes and others (2002) determined that more than twice the distance (about 85 channel widths) was needed to collect 95 percent of the fish species in Oregon rivers. In another study, Patton and others (2000) determined that a mean of $22 \mathrm{X}$ (a 100-m reach length) was required to collect 


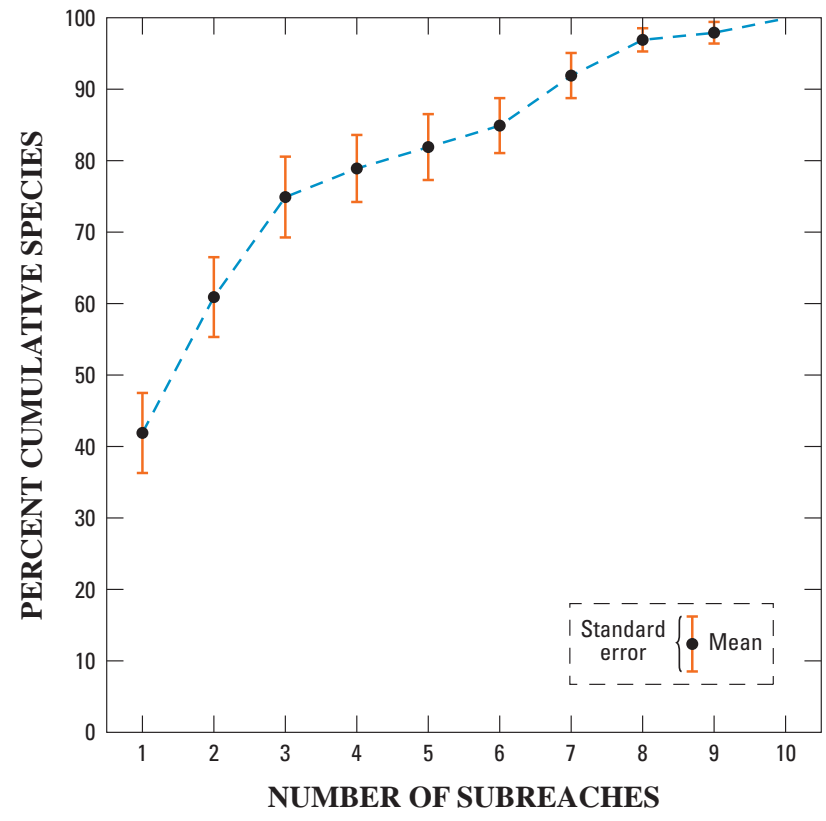

Figure 2. Number of subreaches in relation to percent cumulative fish species collected over a sampling distance of 40 channel widths in 14 river reaches in southern Idaho, 2002.
90 percent of the species in small, wadeable, Wyoming streams.

For the present study, about 250 fish represented 95 percent of the species in a reach (fig. 4). This number is remarkably similar to that of Hughes and others (2002), who determined that at least 225 fish were necessary to represent 95 percent of the species in a reach. On the basis of the number of fish collected from the 14 reaches sampled at $40 \mathrm{X}$, about 8.5 subreaches ( 34 channel widths) would need to be electrofished to collect 250 fish (fig. 5). Mean catch rates (number of fish captured) were very similar among subreaches; no large differences in catch rates between upstream and downstream subreaches were apparent. Additional information from the three reaches sampled at $100 \mathrm{X}$ also showed that a minimum of about 250 fish could be collected by sampling any of the seven subreach combinations equaling 40X (table 4).

The mean ( \pm standard error) catch rates for the reaches sampled at $40 \mathrm{X}$ and $100 \mathrm{X}$ were $28.9 \pm 2.3(\mathrm{n}=14)$ and 90.3 $\pm 10.9(\mathrm{n}=3)$ individuals per subreach, respectively. This catch rate is about 3 times higher than that of Hughes and others (2002), whose mean ( \pm standard error) catch rate was 24.6 \pm 2.5 individuals per subreach for 45 Oregon river reaches sampled at 100X. Reasons for this large difference in catch rate are unclear but could be related to differences in river conditions or fish abundances. Perhaps Oregon reaches were more difficult to sample because of faster velocities or more complex physical habitats. According to Hughes and others
(2002), the mean gradient for 45 streams sampled in Oregon was 0.8 percent (range 0.2 to 2.6 percent). Gradients for raft sites sampled in this study were highest at Payette River near Emmett (0.3 percent), Snake River at Heise ( 0.4 percent), and Salmon River near Challis and Salmon (0.6 percent). Gradients at most other boat sites sampled generally were less than 0.1 percent. These comparisons indicate that streams sampled in southern Idaho were of lower gradient (more "flat water") than those sampled by Hughes and others (2002). This may, at least in part, explain the higher catch rate of fish in this study than in the study of Hughes and others (2002). Another reason for the difference could be the type of collection gear; rafts were the only gear used for the Oregon study, whereas four gear types were used for this study. The mean catch rate by using a raft was similar to the mean catch rate by using all gear types in this study and, on average, still resulted in more fish collected per subreach than did the Oregon study. The mean ( \pm standard error) catch rates by raft for the reaches sampled at $40 \mathrm{X}$ and $100 \mathrm{X}$ were $28.0 \pm 2.6(\mathrm{n}=8)$ and 87.1 $\pm 9.0(\mathrm{n}=2)$ individuals per subreach, respectively.

Cumulative IBI scores determined for subreaches sampled at the three sites representing 100X showed little variability (fig. 6). Almost no change in the IBI score occurred after four subreaches (40X) were sampled. Mean IBI scores for subreaches sampled at 20X were not significantly different $(\mathrm{p}=0.45, \mathrm{n}=14)$ from scores for subreaches sampled at $40 \mathrm{X}$.

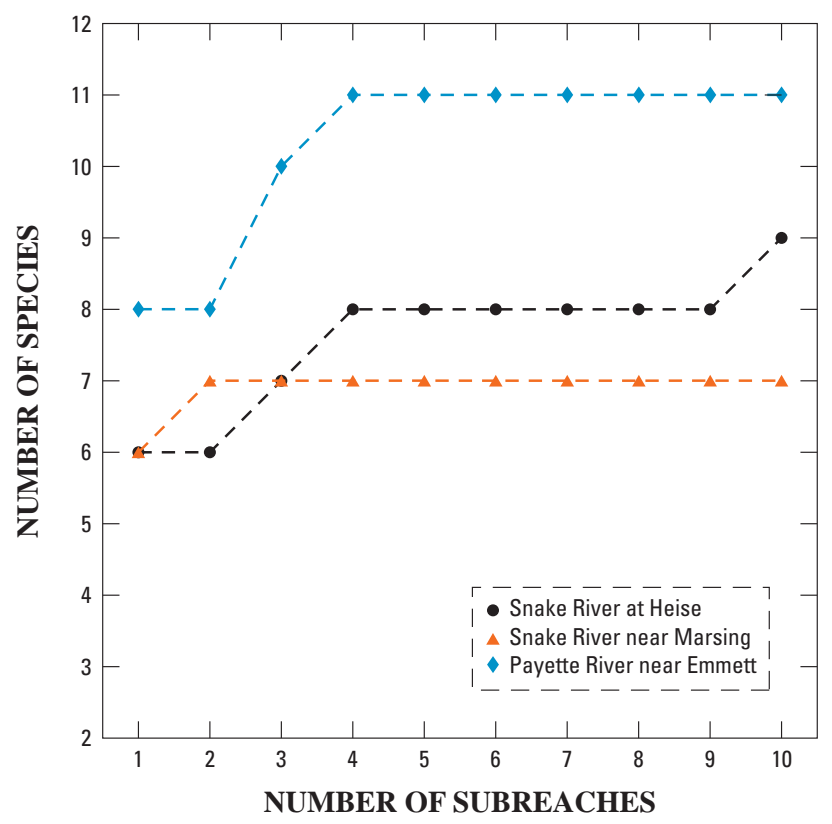

Figure 3. Number of subreaches in relation to number of fish species collected over a sampling distance of 100 channel widths in the Snake River at Heise and near Marsing, and in the Payette River near Emmett, southern Idaho, 2002. 


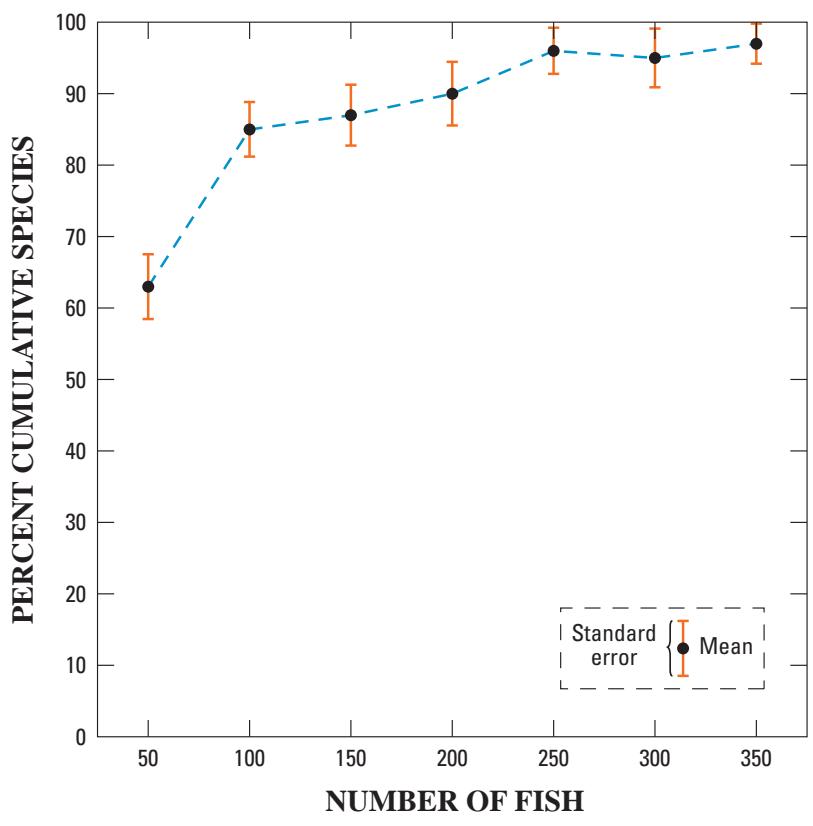

Figure 4. Number of fish in relation to percent cumulative species collected over a sampling distance of 40 channel widths in 14 river reaches in southern Idaho, 2002.

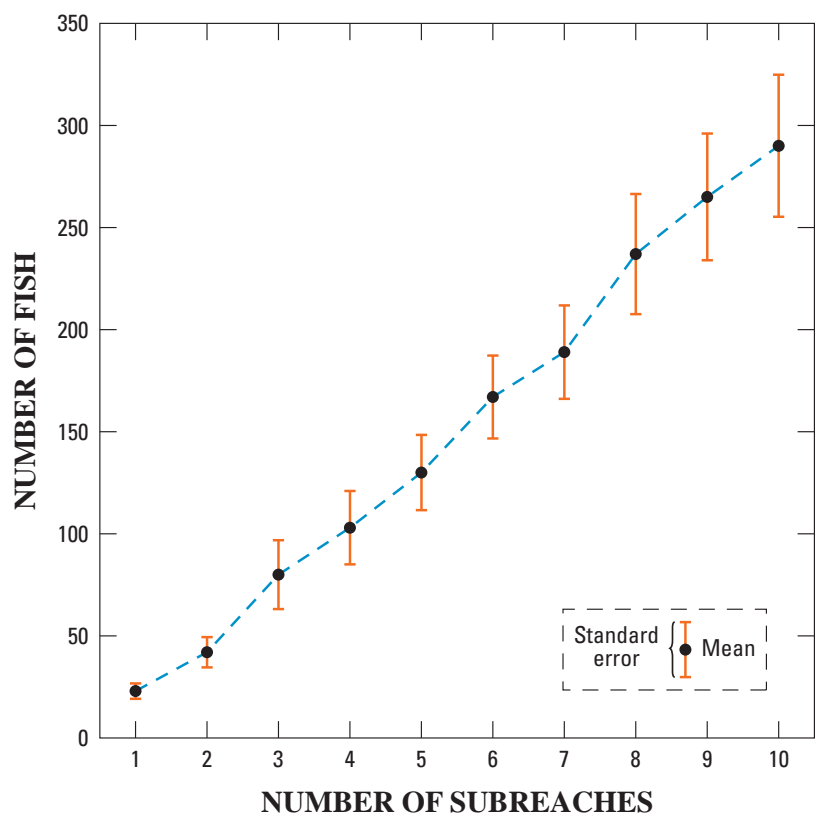

Figure 5. Mean number of fish collected over a sampling distance equal to 40 channel widths in 10 equidistant subreaches in 14 river reaches in southern Idaho, 2002.
However, the fish population collected in a reach sampled at 20X, or five subreaches in a 40X reach, represented only about 80 percent of all the species in the reach (fig. 2). A summary of all possible contiguous subreaches equaling $40 \mathrm{X}$ at the three sites representing 100X showed little difference in IBI scores (table 4). IBI score ranges were 66 to 71 for the Snake River at Heise, 12 to 15 for the Snake River near Marsing, and 21 to 34 for the Payette River near Emmett.

\section{Sampling Variability}

Two duplicate samples showed some spatial or temporal variability. The spatial duplicate samples collected at Rock Creek at Twin Falls (site 7) at 40X received final IBI scores of 55 and 67. The same number of fish species (9) was collected at each site, and the total number of fish collected at each site was 241 and 260 . Temporal samples collected at the beginning and end of the sampling period (about 3 months between visits) over a reach length of $100 \mathrm{X}$ at the Snake River near Marsing (site 12) showed little difference in IBI scores of 5 and 13. However, the number of species ranged from 9 to 7 , and the total number of fish collected each time was 356 and 967. Even though more than 600 additional fish were collected at the end of the sampling period, the IBI scores still indicated poor biotic integrity. This large difference in the number of fish may have been related to river conditions, water clarity, and the lack of abundant macrophyte growth at the end of the sampling period, which made it easier to observe and collect more fish.

\section{Minimum Sampling Effort}

Results of this assessment of sampling efficiency using multiple gear types in a wide range of rivers in southern Idaho showed that a reach length of 30 to $40 \mathrm{X}$ the wetted channel width is generally sufficient to collect an adequate number of fish to estimate species richness and to evaluate biotic integrity using an IBI approach. This conclusion is contingent on a catch rate similar to that achieved in this study. Using channel widths listed in table 1, the median reach lengths of 30 and 40X equate to sampling distances of 1,200 and 1,600 m, respectively. These distances are similar to the 1,600-m (1.6$\mathrm{km})$ sampling distance that Lyons and others (2001) recommended for large rivers in Wisconsin. 
in the column labled "IBI score," all values should be divided by $0.9(9 / 10)$ to be consistent with IBI

described in Mebane and others, 2003.

See Errata, inside cover.

Table 4. Index of Biotic Integrity (IBI) scores and number of fish species and individuals collected at three sites in a reach length of 100 times the channel width sampled for the Environmental Monitoring and Assessment Program, southern Idaho, 2002

[Data are for the seven possible contiguous subreach combinations equaling 40 times the channel width; No., number; locations shown in figure 1]

\begin{tabular}{|c|c|c|c|c|c|}
\hline $\begin{array}{l}\text { Site } \\
\text { No. }\end{array}$ & Site name & $\begin{array}{l}\text { Sub- } \\
\text { reach }\end{array}$ & $\begin{array}{c}\text { IBI } \\
\text { score }\end{array}$ & $\begin{array}{l}\text { No. of } \\
\text { fish } \\
\text { species }\end{array}$ & $\begin{array}{c}\text { No. } \\
\text { of } \\
\text { fish }\end{array}$ \\
\hline \multirow{8}{*}{1} & \multirow{7}{*}{ Snake River at Heise } & $A-D$ & 71 & 8 & 447 \\
\hline & & $B-E$ & 70 & 8 & 372 \\
\hline & & $\mathrm{C}-\mathrm{F}$ & 68 & 8 & 377 \\
\hline & & $\mathrm{D}-\mathrm{G}$ & 70 & 7 & 497 \\
\hline & & $\mathrm{E}-\mathrm{H}$ & 66 & 8 & 424 \\
\hline & & F-I & 67 & 8 & 391 \\
\hline & & G-J & 68 & 9 & 357 \\
\hline & Mean & & 69 & 8 & 409 \\
\hline \multirow{8}{*}{12} & \multirow{7}{*}{$\begin{array}{l}\text { Snake River near } \\
\text { Marsing }\end{array}$} & $A-D$ & 13 & 7 & 511 \\
\hline & & B-E & 13 & 6 & 612 \\
\hline & & $\mathrm{C}-\mathrm{F}$ & 13 & 6 & 695 \\
\hline & & $\mathrm{D}-\mathrm{G}$ & 13 & 6 & 583 \\
\hline & & $\mathrm{E}-\mathrm{H}$ & 12 & 6 & 383 \\
\hline & & F-I & 13 & 6 & 283 \\
\hline & & $\mathrm{G}-\mathrm{J}$ & 15 & 6 & 214 \\
\hline & Mean & & 13 & 6 & 469 \\
\hline \multirow{8}{*}{14} & \multirow{7}{*}{$\begin{array}{l}\text { Payette River near } \\
\text { Emmett }\end{array}$} & $\mathrm{A}-\mathrm{D}$ & 29 & 11 & 236 \\
\hline & & $B-E$ & 27 & 9 & 258 \\
\hline & & $\mathrm{C}-\mathrm{F}$ & 30 & 9 & 229 \\
\hline & & $\mathrm{D}-\mathrm{G}$ & 21 & 7 & 202 \\
\hline & & E-H & 24 & 7 & 220 \\
\hline & & $\mathrm{F}-\mathrm{I}$ & 27 & 7 & 261 \\
\hline & & G-J & 34 & 7 & 336 \\
\hline & Mean & & 27 & 8 & 249 \\
\hline
\end{tabular}

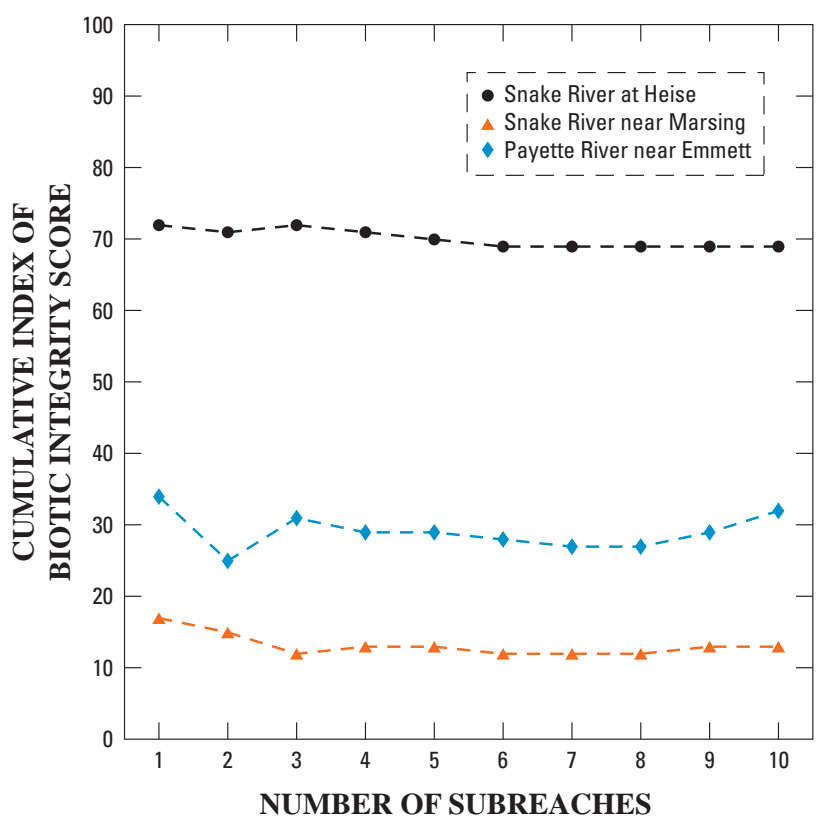

Figure 6. Cumulative Index of Biotic Integrity scores over a sampling distance equal to 100 channel widths in 10 equidistant subreaches in the Snake River at Heise and near Marsing, and in the Payette River near Emmett, southern Idaho, 2002.

Results from this study also suggest that a sample population of fish collected in a minimum reach length of $20 \mathrm{X}$ might be sufficient to evaluate fish assemblages using the IBI but would represent only about 80 percent of all the species present in the reach. Depending on monitoring needs and objectives, it may not be cost effective to spend additional sampling effort at a site to collect rare species. Because the IBI score is based primarily on the relative abundances of the most abundant species, the addition of a few rare species would not greatly influence the final score. However, in most cases, about 250 fish would need to be collected to effectively represent 95 percent of the species present.

\section{Summary and Conclusions}

Fish sampling was conducted at 17 large-river sites during low-flow conditions (July 25 through October 2) in 2002 following U.S. Environmental Protection Agency Environmental Monitoring Assessment Program (EMAP) protocols. Site selection was based on a random selection process of Idaho rivers in the Basins Bioregion of southern Idaho that were equal to or greater than fifth order on 1:100,000-scale hydrographic maps. Fourteen reaches, which included one duplicate (total of 13 sites) were electrofished over a reach 
length representing 40 times $(40 \mathrm{X})$ the wetted channel width. The remaining three sites were electrofished at a reach length representing 100X the wetted channel width to evaluate information gained by additional sampling effort. All reaches sampled were divided into 10 continuous subreaches of equal length to enable calculation of statistical relations between sampling effort and species collection. Because of the wide variety of field conditions encountered, four electrofishing methods were used that consisted of a single pass through a reach. All fish were identified to species, counted, and measured (minimum and maximum total length). External anomalies (deformities, eroded fins, lesions, and tumors) also were recorded.

Fish assemblages were analyzed on the basis of abundances of individuals and species and the Index of Biotic Integrity (IBI). Geographic origin (native or alien), tolerance to pollution, and temperature preferences were assigned to each species. The Zoogeographic Integrity Coefficient (ZIC), an index derived from the ratio of the number of native species to the total number of species, was used to evaluate the degree of habitat disturbance. Various statistical relations between sampling effort and species collection were calculated to evaluate information gained from additional collection effort in successive subreaches.

Thirty-two species of fish in the families Catostomidae, Centrarchidae, Cottidae, Cyprinidae, Ictaluridae, Percidae, and Salmonidae were collected. Twelve alien species representing about 38 percent of all species were collected. Many of these alien species such as sunfish (Centrarchidae), common carp (Cyprinidae), and catfish (Ictaluridae) are adapted for warmwater habitats, especially those habitats created by impoundments. About 53 percent ( 9 of 16 sites, excluding site 8 with only 3 fish), received IBI scores of $<50$, which indicates poor biotic integrity. These sites typically contained few or no coldwater or sensitive species, and the assemblage was composed of predominantly tolerant cool or warmwater species. No sites received high IBI scores (>75). West Fork Bruneau River near Grasmere and the two Salmon River sites near Challis and Salmon received high ZIC index values of 1.0, indicating no habitat disturbance.

On the basis of 14 reaches sampled at $40 \mathrm{X}$, fish collected in about 7.5 subreaches ( 30 channel widths) represented about 95 percent of the species present in the entire reach. Collections in three different reaches sampled at 100X also supported this finding. Few, if any, additional species were collected after sampling 30 to $40 \mathrm{X}$ (three to four subreaches) the channel width at those sites representing $100 \mathrm{X}$. In most cases, about 250 fish were needed to effectively represent 95 percent of the species present. On the basis of the number of fish collected from the 14 reaches sampled at $40 \mathrm{X}$, about 8.5 subreaches ( 34 channel widths) would need to be electrofished to collect 250 fish. Additional information from the three reaches sampled at $100 \mathrm{X}$ also showed that a minimum of about 250 fish could be collected by sampling any of the seven subreach combinations equaling $40 \mathrm{X}$. The mean ( \pm standard error) numbers of fish captured in the reaches sampled at $40 \mathrm{X}$ and
$100 X$ were $28.9 \pm 2.3(n=14)$ and $90.3 \pm 10.9(n=3)$ individuals per subreach, respectively.

Results of this assessment of sampling efficiency using multiple gear types in a wide range of rivers in southern Idaho showed that a reach length of 30 to $40 \mathrm{X}$ the wetted channel width is generally sufficient to collect an adequate number of fish to estimate species richness and to evaluate biotic integrity using an IBI approach. This conclusion is contingent on a catch rate similar to that achieved in this study. Analyses also suggested that, in most cases, about 250 fish would need to be collected to effectively represent 95 percent of the species present. Median reach lengths of 30 and $40 \mathrm{X}$ equate to sampling distances of 1,200 and 1,600 m, respectively.

Results from this study may be applicable to other semiarid, fifth- through seventh-order southern Idaho rivers that are sampled during summer low-flow conditions. Several conclusions reached during this study would benefit future EMAP studies: (1) The wide range of river conditions encountered in southern Idaho made it impractical to rely on one gear type or collection method to effectively sample all sites. The flexibility to choose gear type most appropriate for stream conditions likely improved capture efficiency. Reliance on only one gear type (for example, raft) may restrict capture efficiency at sites where wading methods may be more effective. (2) It is of paramount importance that the field crew include an experienced fishery biologist familiar with a variety of electrofishing methods and the handling and identification of regional fish fauna. (3) Large-river work in the West demands that crew members be trained and skillful in the use of rafts and jet boats in highvelocity rivers. (4) It would be desirable to determine salmonid and cottid age classes within the sampling reach to more effectively utilize the IBI developed specifically for Idaho rivers. (5) A thorough reconnaissance of each candidate site prior to sampling would provide critical information that is desirable for an effective and safe sampling effort.

\section{References Cited}

Behnke, R.J., 1992, Native trout of western North America: Bethesda, Md., American Fisheries Society Monograph 6, $275 \mathrm{p}$.

Brennan, T.S., Lehmann, A.K., Campbell, A.M., O'Dell, I., and Beattie, S.E., 2003, Water resources data, Idaho, water year 2002, v. 1, Great Basin and Snake River Basin above King Hill: U.S. Geological Survey Water Data Report ID-02-1, 419 p.

Cao, Y., Larsen, D.P., Hughes, R.M., Angermeier, P.L., and Patton, T.M., 2002, Sampling effort affects multivariate comparisons of stream assemblages: Journal of the North American Benthological Society, v. 21, no. 4, p. 701-714.

Chandler, J.A., and Radko, M., 2001, Introduction and overview, in Chandler, J.A., ed., Chapter 1. Feasibility of reintroduction of anadromous fish above or within the 
Hells Canyon Complex, technical appendix E.3.1-2 for Hells Canyon Complex Hydroelectric Project FERC No. 1971: Boise, Idaho Power Company, 20 p.

Dynesius, M., and Nilsson, C., 1994, Fragmentation and flow regulation of river systems in the northern third of the world: Science, v. 266, p. 753-762.

Elvira, B., 1995, Native and exotic freshwater fishes in Spanish river basins: Freshwater Biology, v. 33, p. 103-108.

Flotemersch, J.E., and Cormier, S.M., 2001, Comparisons of boating and wading methods used to assess the status of flowing waters: Cincinnati, Ohio, U.S. Environmental Protection Agency, National Exposure Research Laboratory, EPA/600/R-00/108, 93 p.

Galat, D.L., and Zweimuller, I., 2001, Conserving large-river fishes: is the highway analogy an appropriate paradigm: Journal of the North American Benthological Society, v. 20, no. 2, p. 266-279.

Grafe, C.S., Mebane, C.A., McIntyre, M.J., Essig, D.A., Brandt, D.H., and Mosier, D.T., 2002, The Idaho Department of Environmental Quality water body assessment guidance, second edition-final: Boise, Idaho Department of Environmental Quality, [variously paged].

Hughes, R.M., Kaufman, P.R., Herlihy, A.T., Intelmann, S.S., Corbett, S.C., Arbogast, M.C., and Hjort, R.C., 2002, Electrofishing distance needed to estimate fish species richness in raftable Oregon rivers: North American Journal of Fisheries Management, v. 22, p. 1229-1240.

Karr, J.R., 1991, Biological integrity: a long-neglected aspect of water resource management: Ecological Applications v. 1 , no. 1, p. 66-84.

Leopold, L.B., Wolman, M.G., and Mill, J.P., 1964, Fluvial processes in geomorphology: San Francisco, Calif., W.H. Freeman Press, 522 p.

Li, H.W., Schreck, C.B., Bond, C.E., and Rexstad, E., 1987, Factors influencing changes in fish assemblages of Pacific Northwest streams, in Matthews, W.J., and Heins, D.C., eds., Community and evolutionary ecology of North American stream fishes: Norman, Okla., University of Oklahoma Press, p. 193-202.

Lyons, J., 1992, The length of stream to sample with a towed electrofishing unit when fish species richness is estimated: North American Journal of Fisheries Management, v. 12, p. 198-203.

Lyons, J., Piette, R.R., and Niermeyer, K.W., 2001, Development, validation, and application of a fish-based index of biotic integrity for Wisconsin's large warmwater rivers: Transactions of the American Fisheries Society, v. 130, p. 1077-1094.

Maret, T.R., 1995, Water-quality assessment of the upper Snake River Basin, Idaho and western Wyoming - summary of aquatic biological data for surface water through 1992: U.S. Geological Survey Water-Resources Investigations Report 95-4006, 59 p.
1997, Characteristics of fish assemblages and related environmental variables for streams of the upper Snake River Basin, Idaho and western Wyoming, 1993-95: U.S. Geological Survey Water-Resources Investigations Report 97-4087, 50 p.

Meador, M.R., Cuffney, T.E., and Gurtz, M.E., 1993, Methods for sampling fish communities as part of the National Water-Quality Assessment Program: U.S. Geological Survey Open-File Report 93-104, 40 p.

Meador, M.R., McIntyre, J.P., and Pollock, K.H., 2003, Assessing the efficacy of single-pass backpack electrofishing to characterize fish community structure: Transactions of the American Fisheries Society, v. 132, p. 3946.

Mebane, C.A., Maret, T.R., and Hughes, R.M., 2003, An index of biological integrity (IBI) for Pacific Northwest Rivers: Transactions of the American Fisheries Society, v. 132, p. 239-261.

Miller, R.R., Williams, J.D., and Williams, J.E., 1989, Extinction of North America fishes during the past century: Fisheries, v. 14, no. 6, p. 22-38.

Moyle, P.B., 1994, Biodiversity, biomonitoring, and the structure of stream fish communities, in Loeb, S.L., and Spacie, A., eds., Biological monitoring of aquatic systems: Boca Raton, Fla., Lewis Publishers, p. 171-186.

Omernik, J.M., and Gallant, A.L., 1986, Ecoregions of the Pacific Northwest: Corvallis, Oreg., U.S. Environmental Protection Agency, EPA 600/3-86/033, 39 p.

Patton, T.M., Hubert, W.A., Rahel, F.J., and Gerow, K.G., 2000, Effort needed to estimate species richness in small streams on the Great Plains in Wyoming: North American Journal of Fisheries Management, v. 20, p. 394-398.

Peck, D.V., Averill, D.K., Lazorchak, J.M., and Klemm, D.J., eds., 2002, Environmental monitoring and assessment program-surface waters: western pilot study: field operations manual for non-wadeable rivers and streams (Draft): Corvalis, Oreg., U.S. Environmental Protection Agency, 198 p.

Peck, D.V., Lazorchak, J.M., and Klemm, D.J., eds., 2001, Environmental monitoring and assessment programsurface waters: western pilot study: field operations manual for wadeable streams (Draft): Corvalis, Oreg., U.S. Environmental Protection Agency, 242 p.

Reash, R.J., 1999, Considerations for characterizing Midwestern large-river habitats, in Simon, T.P., ed., Assessing the sustainability and biological integrity of water resources using fish communities, chapter 17: Boca Raton, Fla., CRC Press, p. 463-473.

Simon, T.P., and Sanders, R.E., 1999, Applying an Index of Biotic Integrity based on Great-River fish communities: considerations in sampling and interpretation, pages 475-505, in Simon, T.P., ed., Assessing the sustainability and biological integrity of water resources using fish 
communities: Boca Raton, Fla., CRC Press, Lewis Publishers, $671 \mathrm{p}$.

Strahler, A.N., 1957, Quantitative analysis of watershed geomorphology: Transactions of the American Geophysical Union, v. 38, p. 913-920.

Warren, M.L., Jr., and Burr, B.M., 1994, Status of freshwater fishes of the United States-overview of an imperiled fauna: Fisheries, v. 19, no. 1, p. 6-18.
Wilkinson, L., 1999, SYSTAT for Windows-statistics, version 9.0: Evanston, Ill., SPSS, Inc., 660 p.

Zaroban, D.W., Mulvey, M.P., Maret, T.R., Hughes, R.M., and Merritt, G.D., 1999, Classification of species attributes for Pacific Northwest freshwater fishes: Northwest Science, v. 73, no. 2, p. 81-93. 


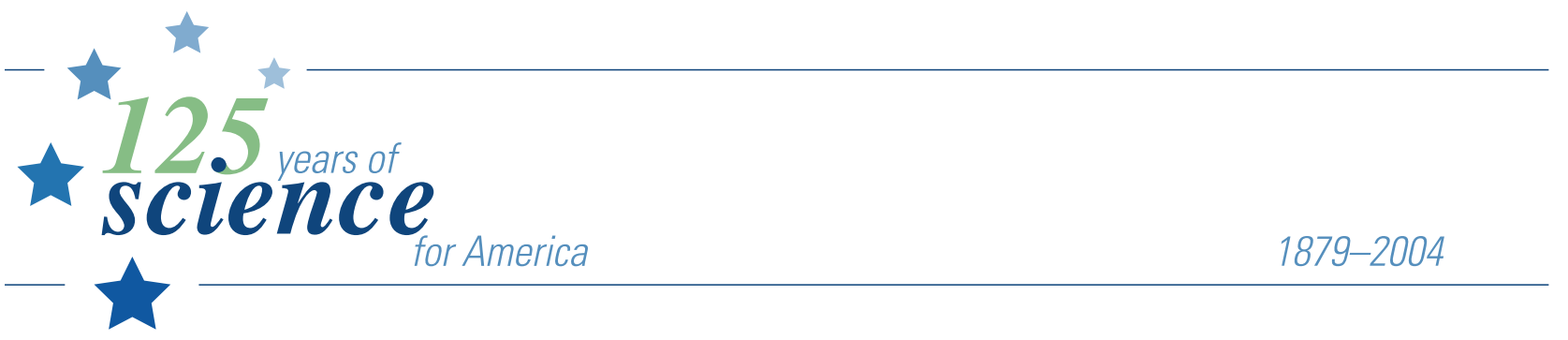

